\title{
A Study on the Ideological Basis of the CPC's Leadership in Literary and Artistic Work during the New Democratic Revolution
}

\author{
Wei Zheng ${ }^{1}$ \\ ${ }^{1}$ School of Marxism Studies, Central University of Finance and Economics, Beijing, China \\ Correspondence: Wei Zheng, School of Marxism Studies, Central University of Finance and Economics, Beijing 100081, \\ China.
}

Received: June 2, 2020

Accepted: June 28, $2020 \quad$ Available online: June 29, 2020

doi:10.11114/ijsss.v8i4.4915

URL: https://doi.org/10.11114/ijsss.v8i4.4915

\begin{abstract}
The leadership of literary and artistic work is an important part of the revolutionary cause led by the Communist Party of China (hereinafter referred to as "the CPC"). During the new democratic revolution, the ideological basis for the CPC's leadership in literary and artistic work included the literary and artistic thoughts of Marx and Engels, Lenin and Stalin, as well as the traditional Chinese literary and artistic thoughts. These ideological resources provided theoretical guidance for the CPC to lead literary and artistic work in the period of the new democratic revolution, and also provided basic guidelines for the CPC to formulate policies on literary and artistic work. The study of the ideological basis of the CPC's leadership in literary and artistic work during the new democratic revolution is of great historical significance for promoting the development of Chinese literary and artistic undertakings in the new era.
\end{abstract}

Keywords: new democratic revolution, the communist party of China, literary and artistic work, ideological basis

\section{Introduction}

During the new democratic revolution, the leadership of literary and artistic work was an important part of the revolutionary cause led by the CPC. Any social practice has its ideological roots. The ideological basis of the CPC's leadership in literary and art work is Marxism and traditional Chinese literary and art thought. Marxist thought on literature and art is mainly expounded by Marxist classical writers, including Marx and Engels' thought on literature and art, as well as Lenin's thought on literature and art, who led the establishment of the Soviet Union, and Stalin's thought on literature and art, who led the revolutionary construction of the Soviet Union. At the same time, during the new democratic revolution, the CPC led the literary and artistic work to gradually succeed, which was inseparable from the development of literary and artistic work in combination with the specific actual situation of Chinese society. The CPC has absorbed the outstanding parts of Chinese traditional literary and artistic thoughts. Therefore, Chinese traditional literary and artistic thoughts are also the ideological source of the Party's leading literary and artistic work.

\section{Marx and Engels' Thought on Literature and Art}

As a constituent part of ideology, Marx and Engels paid much attention to the development of literature and art and put forward many discussions on literature and art. As Marx and Engels's literary thoughts, as in politics, economics and other related works and letters, such as "holy family", "the German ideology", "economic and philosophical manuscripts in 1844, the communist manifesto," preface to a contribution to the critique of political economy and other work, as well as the letter of Marx and Engels. The main content involves the relationship between literature and art and material, the relationship between art production and material production, the production process of literature and art, literary criticism, the relationship between literature and art and politics and society, the value of literature and art. These ideological elements provided theoretical guidance for the CPC to lead literary and artistic work during the new democratic revolution, and also provided basic guidelines for the CPC to formulate policies on literary and artistic work.

\subsection{The Scientific View of Literature and Art Should Be Based on Marxist Materialist Dialectics}

Marxist classical writers believe that literature and art are a kind of ideology. Marxism has clearly explained to us the general law of social development. Social existence determines social consciousness, while economic basis determines superstructure. Therefore, as an ideology, literature and art are based on the material basis of the objective existence of 
society, and the scientific view of literature and art is based on dialectical materialism and historical materialism.

In preface to the critique of political economy, Marx points out that...In examining these changes, it must be time to separate the following two: one is the economic conditions of production material, can indicate the change of the accuracy of the natural science, is a kind of people so as to realize the conflict and strive to overcome it the legal, political, religious, or philosophy of art, in short, the ideological form (Marx, 2012).Engels believed that people first had to eat, drink, live and wear before they could engage in politics, science, art, religion and so on. Therefore, the direct production of the material means of subsistence, and thus the certain stage of economic development of a nation or an era, constitutes the basis... The concept of art and even religion develops from this foundation, so it must be explained by this foundation, instead of doing the opposite as in the past (Engels, 2012).The discussion of Marx and Engels shows that literature, art, politics, law and so on, in the final analysis, are determined by economic factors, that is, by the material basis and social existence. The basic source of literature and art is human social practice. Material production and social practice are the most important, and literature and art are the practical activities of human beings in the field of social consciousness.

At the same time, literature and art have their own laws. While emphasizing that the material basis of society determines the development of literature and art, Marx and Engels also pointed out dialectically that literature and art are a "special" spiritual production, and literature and art are "constructed according to the law of beauty", pointing out the relative independence of literature and art. This relative independence is reflected in two aspects. On the one hand, literature and art have a relatively independent production process. Marx pointed out that religion...Law, morality, science, art, etc., are but special modes of production, and are governed by the universal laws of production. On the basis of being determined by universal laws, the production of literature and art has its special and unique laws. Art objects create the public who understand art and have aesthetic ability (Marx, 2012).This special production process is the development law of literature and art. Literature and art, as a special spiritual production, has its own laws of development and is internally unified in the general law of social production in the material development. On the other hand, the development of literature and art is not always in balance with the development of society. The balance here mainly compares the balance between literature and art and the economy. In general, the development of literature and art is consistent with the development of society, but there is also an imbalance between the development of literature and art and the development of society. This understanding of the law of literature and art will help us to grasp a scientific perspective when studying the work of literature and art led by the CPC and avoid metaphysics and bolognalism.

Scientific thought leads scientific methodology. The view of literature and art based on Marxist materialist dialectics provided a correct methodology for the CPC to lead the work of literature and art scientifically during the new democratic revolution. During the new democratic revolution, under the guidance of Marxism, literary and artistic work under the leadership of the CPC gradually broke away from the non-mainstream literary and artistic form of the old democratic society and grew into the mainstream literary and artistic form of the proletariat. Only by applying the scientific methods of dialectical materialism and historical materialism, and combining the general laws of social movements with the unique laws of the development of literature and art itself, can we sum up practical experience and formulate correct literature and art policies for the leadership of the CPC in the work of literature and art.

\subsection{Literature and Art Have the Characteristics of Class}

Marx and Engels believed that literature and art have class nature. In the 19th century, they proposed that literature and art should glorify the proletariat, and that artists should "glorify the stubborn, all-powerful and revolutionary proletarians."

The production of literature and art is inseparable from social existence. In class society, literature and art always represent the interests of the ruling class, represent the will of the ruling class, and maintain the rule of the ruling class. In other words, literature and art are restricted by the ruling class in class society. In class society, the ruling class expresses the thoughts and wills of the ruling class in literary and artistic forms, so that the ruled class can accept their own thoughts. On the other hand, although the ruling class is in a position of acceptance, it also tries hard to produce literary works of its own class in the confrontation with the ruling class. However, in any case, the dominant literature and art is always the literary works and literary thoughts that express the will of the ruling class. In different historical stages of human society, literature and art changed with the change of the status of a certain class in the society.

Engels pointed out that the main value of Schiller's plot and love was that it was the first politically inclined drama in Germany (Engels, 2009).Engels spoke highly of the international because it made clear to the public its political views and expressed its own political tendencies. Later Lenin also praised Gorky's "mother" for its open political views. Therefore, Marxist classical writers believe that literature and art should have a certain tendency. This tendency is closely related to the objective social environment of art production. "The more obscure the author's views, the better 
for the work of art. The realism I mean can even be expressed against the author's opinion. Artists, because they are in a certain class position, inevitably suffer from the limitations of their own class in their creation, which, in the view of Marx and Engels, should be allowed.

The CPC represents the fundamental interests of the overwhelming majority of the people and is the vanguard of the Chinese people and the Chinese nation. This important attribute of the class nature of literature and art has made clear the class orientation for the CPC to lead the work of literature and art in the period of the new-democratic revolution, and pointed out the direction for the party to formulate literature and art policies and carry out literature and art practice.

\subsection{Practicality Is an Important Feature of Literature and Art}

The source of literary and artistic activities is based on practical activities, which, under certain conditions, can react on practical activities. The old materialists saw that literature and art reflected the real life, but they did not see the dialectical relationship between literature and art, real life and social existence. Chernyshevsky, for example, admitted that "beauty is life", but he also believed that art cannot be higher than life. This is the limitation of the old materialism.

Marx and Engels studied literature and art from the perspective of dialectical materialism and historical materialism. Marx said, labor produces beauty. The emergence, development and change of literature and art are closely connected with material basis and practical activities. Marx and Engels believed that literature and art originated from social practice, reflected social practice, and could react on social practice under certain circumstances. Mr. Coase in the sensitization, kitschy (on November 26, 1885) in a letter on the reality of bias and expounds the viewpoint that mentioned if the novel with a socialist orientation through the true portrayal of the real relationship, to break the traditional popular fantasy about these relationships, shake the optimism of the bourgeois world, inevitably lead to suspicion of existing things forever...(Engels, 2009) and Engels had outstanding master of realism Balzac, for example, he told us deeply, on the one hand, Balzac has political bias and prejudice, on the other hand is his observation of the reality, can see the historical inevitability, after analysis and study enthusiasm Acura masses, which betrayed his class. Therefore, the tendentiousness and authenticity in literary and artistic works are dialectically unified.

During the period of the new-democratic revolution, the CPC was truth-seeking and pragmatic. It always led literature and art work in exploration after exploration in the light of the principal social contradiction and the practice of the revolutionary struggle. In the course of leading the work of literature and art, the CPC has used Marxist scientific theories to guide practice, discovered problems in the struggle against revolutionary literature and art, solved practical problems in the work of literature and art, and used literary and artistic works that reflect practice as weapons to promote the continuous development of the practice of revolutionary struggle.

\subsection{The Value of Literature and Art is to Promote Human Liberation and All-Round Free Development}

The ultimate value pursuit of Marxism is the comprehensive and free development of human beings, and Marxist thought on literature and art has a unique value orientation. Marxist literature and art studies believe that literature and art should reflect the trend of social and historical development and promote the liberation of human beings and their comprehensive and free development.

With the development of human society from the lower level to the higher level, literature and art should actively reflect the historical development trend of human society. Marx and Engels were opposed to transforming the realistic social movement, which had already become the pioneer of severe social changes in all civilized countries, into a comfortable and peaceful change and a quiet and comfortable life (Marx, Engels, 2016).On the one hand, it affirms the progress of the capitalist society replacing the feudal patriarchal society; on the other hand, it sharply criticizes the conservatism and the trend of thought of restoring ancient ways which want to go back to the idyllic rural commune. History is the history of human society, people are also historical people, people are the main body of social and historical development, but also the promoter of social and historical development. Marxist literature and art are closely related to human development. Marx and Engels thought, "' liberation 'is a historical activity, not an ideological activity. "Marxism tells us that only the people are the creators of history. Only human social practice can promote the development of social history, is the way to change their own destiny, is the effective way to obtain human liberation and comprehensive free development. This is not only the scientific path for the all-round and free development of human beings, but also the source of the production and creation of literature and art. It is the right path for the CPC to lead the work of literature and art towards prosperity and development.

\section{The Literary and Artistic Thoughts of Lenin and Stalin}

While inheriting and developing Marxist theory, Lenin and Stalin also inherited and developed the literary and artistic thoughts of Marx and Engels. During the Russian revolution, Lenin put forward many insightful literary ideas. During the construction of the Soviet union, Lenin and Stalin promoted the new development of Marxist thought on literature and art. 


\subsection{Lenin's Thought on Upholding Party Spirit in Literature and Art}

Lenin lived in an age of war and revolution. In "party organizations and party publications" (1905), Lenin discussed the dialectical relationship between literature and revolution, and clearly pointed out the party spirit of proletarian literature. Under the historical conditions of the revolutionary struggle in Russia, Lenin creatively clarified the class nature of Marxist literature and art into the party spirit of literature and art. From literary and artistic works must be ideological, tendentiousness, class, further elaborated to literary and artistic works must have party spirit. So, why say class sex to focus on party spirit to come up? In his view, strict party spirit is the companion and result of highly developed polar-class struggle. On the contrary, in order to carry out class struggle openly and extensively, strict party spirit must be developed. Therefore, the party of the conscious proletariat, the social Democratic Party, should fight against the non-party spirit at all times and make unremitting efforts to build a close-knit socialist workers' party that sticks to its principles (Lenin, 1995).

Lenin believed that as long as there were classes in society, literary and artistic workers could not work independently of social life while creating works in that society. In Lenin's view, literature and art should adhere to the party spirit, mainly reflected in the two specific aspects of literature and art to serve the masses and proletarian revolution.

On the one hand, literature and art should serve the masses and arouse artists among the masses. In party organizations and party publications, Lenin put forward the famous view that "literature and art should serve millions of working people" very early, emphasizing the direction that literature and art should serve the working people. After the victory of the October revolution, Lenin gave high praise to the writers for writing a book for the laborers, the real masses of the people, the ordinary workers and peasants (Lenin, 1960).Lenin clearly pointed out that art belongs to the people. It must have its deepest roots at the bottom of the working masses. It must be known and loved by these masses....It must call its artists among the masses and develop them. Not only should the production and creation of literature and art serve the working people, but artists should also be "awakened" in the process of serving thousands of working people and become artists who create for the people. After the victory of the October revolution, Lenin promulgated a number of policies and regulations in the Soviet union, promoting the idea of literature and art serving the working people as his practice of leading the Soviet union's literature and art.

On the other hand, literature and art should serve the proletarian revolution. In the party's organization and its publications, Lenin thought, publications should be "truly advanced, complete with revolutionary class sports together", represented by literary works of literary and artistic works, including all of the published works, shall be the party's published works, they will have the feature of social democracy, to serve for the proletariat revolution. For example, in his communication with Leo Tolstoy, Lenin evaluated him as a mirror of the Russian revolution. Lenin affirmed and praised his works, which reflected some essential things of the revolution, and his literary and artistic works, which reflected the political tendencies and demands of the proletariat.

\subsection{Stalin's Literary and Artistic Thoughts Reflecting Patriotism}

On the principles of literary and artistic creation, Stalin believed that literary and artistic works should express and reflect the spirit of patriotism. Stalin expressed his views on literary and artistic creation in his letter to comrade Jamyan bedennay. Generally speaking, the general tone of Stalin's thought on literature and art is patriotism.

In his works, the Soviet writer Jemyan gradually amplified his criticism of the shortcomings of the social life of the Soviet union into his dissatisfaction with the whole Soviet union, which reflected the obvious tendency of anti-patriotism. Mr Jemyan sees the central decision as a matter of "skewing the rope", sticking to what he calls "art for art's sake". Starting from Jemyan's work itself, Stalin criticized his "art for art's sake" and advocated the separation of art and politics.

It is necessary for the literary and art circles to criticize some problems and shortcomings. However, if Soviet writers and artists indulge in "literature for the sake of literature" and "criticism for the sake of criticism", this is a complete violation of Marxist literary and artistic thought. The Soviet working class, under the leadership of the communist party of the Soviet union, provided a great example for mankind in the struggle for freedom and socialism (Que Yanhua, 2018).For Stalin, it was important for writers and artists to express proletarian patriotism.

In his criticism of jemyan, Stalin also stressed that communist writers must obey party resolutions, understand the essence of party resolutions and correct their own mistakes, and that communist writers must be modest (Stalin, 1984).The writers and artists of the party use literary works to reflect the spirit of patriotism and the great Soviet proletariat. To deal with criticism, writers and artists should accept it humbly and try their best to correct their mistakes. Party members and writers, in particular, must grasp the essence of the party's resolutions and correct their own mistakes.

The discussion of Marxist classical writers is the guiding ideology of the CPC in leading the work of literature and art. 
After the new-democratic revolution, Marxist thought on literature and art spread widely with the spread of Marxist classics, providing a theoretical source for the party to guide literature and art work.

\section{Traditional Chinese Thoughts on Literature and Art}

Chinese traditional literature and art refers to the traditional art formed in the long historical development of the Chinese nation before it entered modern and contemporary society. In terms of its forms, such as the hundred schools of thought, poetry, song ci, yuan miscellaneous songs, Ming and Qing novels, operas, classical dance, classical music, traditional Chinese painting, calligraphy, etc., are all precious pearls of traditional Chinese literature and art. Chinese traditional literature and art pay attention to the three basic characteristics of personality, artistic conception and society, which together form a general thought of literature and art: to experience one's own personality in natural objects, so as to realize the realm of art (Cheng Fuwang, 1989).Chinese traditional literary thought is the embodiment of Chinese traditional cultural thought in literature and art, and its thoughts are extremely rich.

\subsection{The Ethical Spirit of Pursuing Morality}

Chinese traditional literature and art, as an important branch of traditional culture, pays attention to the pursuit of ethics and morality. Confucianism and Taoism complement each other, which is the basic pattern of Chinese traditional literature and art. Since Confucius, the benevolence spirit and ethical culture advocated by Confucian culture have continued to this day. In the Chinese traditional literary and art thought, its philosophy thought core is "benevolence", that is the highest moral ideal. If embodied in the philosophy of social ethics, the core of traditional Chinese literary and artistic thought is "ritual". Finally, in the expression of traditional Chinese literature and art, it is "teaching". That is to say, in traditional Chinese society, literature and art are methods and tools for ideological education. With the help of the education, creation and expression of literature and art, inherit and spread the ethics and morals of the Chinese nation. To some extent, the ancient Chinese social culture was mainly based on ethical culture. As Mr. Luo Guojie pointed out, compared with the west, the traditional Chinese society attaches more importance to the relationship between people and relations (Luo Guojie, 1987).Therefore, the traditional Chinese literary and art thoughts must convey the idea of benevolence, justice, propriety, wisdom and faith. The traditional Chinese literature and art are closely linked with aspiration, personality and life, so that the poem and music are "heartfelt" and the calligraphy and painting are "heart paintings".

\subsection{Pursue the Beauty of the Harmony Between Man and Nature}

The ancients believed that the heaven created all things, and the common origin of man and things is the heaven. To emphasize the artistic conception of literature and art, we should pursue the world view of literature and art that is the unity of man and nature. In the basic pattern of Confucianism, Taoism and literature, Confucianism mainly emphasizes that literature and art write god by form and manifest god by form, while Taoism promotes literature and art to pursue the spirit of "perfection" and "elegance" (Chen Liwen, 2001).Ancient Chinese literature and art pursued the unity of man and nature, the beauty of artistic conception and the beauty of neutralization. Confucius advocated the "fear of the mandate of heaven"; Zhuangzi stressed that "the Lord is also the way of heaven; Minister, humanity also ";Zhu xi believed that "the sky and the earth take living things as their hearts, and the life of people and things is also the heart of the heaven and earth.". It is precisely because the world outlook of traditional Chinese literature and art is based on the unity of man and nature that the traditional Chinese literature and art form emphasizes the beauty of artistic conception, which means to experience one's own personality in natural objects so as to achieve the harmonious balance between man and things. At the same time, "harmony" is an important category in the traditional Chinese cultural philosophy, and "the doctrine of the mean" is also an interpretation of the "harmony" philosophy. Therefore, in the long historical development process, Chinese traditional art pays special attention to the beauty of "neutralization", which is also an expression of the artistic conception of the unity of man and nature. For example, ancient Chinese poetry and painting stress on artistic conception; Classical dance is about balance.

\subsection{Reflect Patriotic Feelings of Home and Country}

In traditional Chinese literature and art there is no lack of the essence of elegance, at the same time, the traditional Chinese literature and art also pay attention to the vicissitudes of the world. Confucius said, "what you know is what you know; what you do not know is what you do not know." In traditional Chinese culture, there has always been a tradition of seeking truth and being pragmatic. This tradition is embodied in literature and art, which pays attention to the society and the country. On this basis, traditional Chinese literary and artistic thoughts embody a strong spirit of patriotism.

Confucianism has been influential since its foundation. Confucius said, "The gentleman worries about the way"; Gu Yanwu put forward: "the rise and fall of the world, every person is responsible." The Chinese civilization has never ceased to flow. From ancient times to the present, patriotism has always flowed through the thoughts of Chinese 
literature and art. Among the various forms of traditional Chinese literature and art, there are abundant patriotic literary and artistic works, such as Qu Yuan's li Sao, Yue Fei Wen Tianxiang's poems, and traditional operas with patriotic themes and so on. Patriotism in traditional Chinese literature and art is also an excellent quality in traditional Chinese culture. This kind of patriotic feelings of home and country are manifested in the sense of hardship, resistance to aggression and foreign aggression, and emphasis on national integrity.

In the historical course of the new democratic revolution, the CPC organically combined Marxist literary and artistic thought with traditional Chinese literary and artistic thought, and formed the Chinese new democratic cultural thought. The essence of traditional Chinese literary and artistic thought, rooted in the spiritual blood of every Chinese, is an important ideological source of the CPC's leadership in literary and artistic work.

\section{The Conclusions}

After the new-democratic revolution, Marxist thought on literature and art spread widely with the introduction of Marxist classics into China, providing an important ideological source for the CPC to guide its literary and artistic work. The ideological basis for the CPC's leadership in literary and artistic work includes the literary and artistic thoughts of Marx and Engels, Lenin and Stalin, as well as the traditional Chinese literary and artistic thoughts. The CPC has organically combined Marxist thought on literature and art with traditional Chinese thought on literature and art, forming the Chinese new democratic cultural thought. These abundant ideological resources provided theoretical guidance for the CPC to lead literary and artistic work during the new democratic revolution, and also provided basic guidelines for the CPC to formulate policies on literary and artistic work.

\section{References}

Chen, L. W. (2001). Taoism and Traditional Chinese Literature and Art. Literary Criticism, 6, 93.

Cheng, F. W. (1989). The Cultural Essence of Traditional Chinese Literature and Art. Seek, 03, 87.

Lenin. (1960). Lenin's Dissertation on Science and Art. Beijing: people's literature publishing house, 1960, 640-641.

Lenin. (1995). Selected Works of Lenin. Beijing: people's publishing house, 1, 662-667.

Luo, G. J. (1987). Basic Characteristics of Chinese Ethical Tradition. Beijing: China Renmin university press, 100.

Marx \& Engels. (2009). Collected Works of Marx and Engels. Beijing: people's publishing house, 10, 545.

Marx \& Engels. (2012). Selected Works of Marx and Engels. Beijing: people's publishing house, 2, 33-693.

Marx \& Engels. (2016). Complete Works of Marx and Engels. Beijing: people's publishing house, 3, 639.

Que, Y. H. (2018). Study on the practice and policy of Chinese communist party. Beijing: Xueyuan press, pp. 30.

Stalin (1984). Stalin's Letter to Comrade Jemyan Bedene. Selected Essays on Literature and Art Policy (internal sources), p52.

\section{Copyrights}

Copyright for this article is retained by the author(s), with first publication rights granted to the journal.

This is an open-access article distributed under the terms and conditions of the Creative Commons Attribution license which permits unrestricted use, distribution, and reproduction in any medium, provided the original work is properly cited. 